The University of Maine

DigitalCommons@UMaine

$1-1-1999$

\title{
Use of antibacterial agents to elucidate the etiology of juvenile oyster disease (JOD) in Crassostrea virginica and numerical dominance of an $\boldsymbol{\alpha}$-proteobacterium in JOD-affected animals
}

\author{
Katherine J. Boettcher \\ University of Maine \\ Bruce J. Barber \\ University of Maine \\ John T. Singer \\ University of Maine
}

Follow this and additional works at: https://digitalcommons.library.umaine.edu/bio_facpub

Part of the Aquaculture and Fisheries Commons

\section{Repository Citation}

Boettcher, Katherine J.; Barber, Bruce J.; and Singer, John T., "Use of antibacterial agents to elucidate the etiology of juvenile oyster disease (JOD) in Crassostrea virginica and numerical dominance of an $\alpha$ proteobacterium in JOD-affected animals" (1999). Biology and Ecology Faculty Scholarship. 9. https://digitalcommons.library.umaine.edu/bio_facpub/9

This Article is brought to you for free and open access by DigitalCommons@UMaine. It has been accepted for inclusion in Biology and Ecology Faculty Scholarship by an authorized administrator of DigitalCommons@UMaine. For more information, please contact um.library.technical.services@maine.edu. 


\title{
Use of Antibacterial Agents To Elucidate the Etiology of Juvenile Oyster Disease (JOD) in Crassostrea virginica and Numerical Dominance of an $\alpha$-Proteobacterium in JOD-Affected Animals $\uparrow$
}

\author{
KATHERINE J. BOETTCHER, ${ }^{1 *}$ BRUCE J. BARBER, ${ }^{1}$ AND JOHN T. SINGER ${ }^{2}$ \\ School of Marine Sciences ${ }^{1}$ and Department of Biochemistry, Microbiology, and \\ Molecular Biology, ${ }^{2}$ University of Maine, Orono, Maine 04469
}

Received 22 December 1998/Accepted 6 April 1999

\begin{abstract}
Since 1988, juvenile oyster disease (JOD) has resulted in high seasonal losses of cultured Eastern oysters (Crassostrea virginica) in the Northeast. Although the cause of JOD remains unknown, most evidence is consistent with either a bacterial or a protistan etiology. For the purpose of discerning between these hypotheses, the antibacterial antibiotics norfloxacin and sulfadimethoxine-ormetoprim (Romet-B) were tested for the ability to delay the onset of JOD mortality and/or reduce the JOD mortality of cultured juvenile $C$. virginica. Hatcheryproduced $C$. virginica seed were exposed in triplicate groups of 3,000 animals each to either norfloxacin, sulfadimethoxine-ormetoprim, or filter-sterilized seawater (FSSW) and deployed in floating trays on the Damariscotta River of Maine on 17 July 1997. Each week thereafter, a subset of animals from each group was reexposed to the assigned treatment. Repeated immersion in either a sulfadimethoxine-ormetoprim or a norfloxacin solution resulted in a delay in the onset of JOD mortality in treated animals and reduced weekly mortality rates. Weekly treatments with either norfloxacin or sulfadimethoxine-ormetoprim also resulted in a statistically significant reduction in cumulative mortality ( 55 and $67 \%$ respectively) compared to animals treated weekly with FSSW $(81 \%)$ or those that had received only a single treatment with either norfloxacin, sulfadimethoxine-ormetoprim, or FSSW (77, 84, and 82\%, respectively). Bacteriological analyses revealed a numerically dominant bacterium in those animals with obvious signs of JOD. Sequence analysis of the 16S rRNA gene from these bacteria indicates that they are a previously undescribed species of marine $\alpha$-proteobacteria.
\end{abstract}

The Eastern oyster, Crassostrea virginica, is the primary species of bivalve cultured in the northeastern United States (41). Growers who use hatchery-produced seed maintain the juveniles in floating trays for the first season of maturation. Epizootics of $C$. virginica during this "nursery" phase were unknown prior to the emergence of juvenile oyster disease (JOD) in the late 1980s. JOD has since become enzootic in several growout sites in Maine, Massachusetts, and New York, where annual JOD-attributable losses may exceed $90 \%$ of the total production $(9,12)$.

JOD affects only cultured Eastern oysters, and although the impact of this disease may vary from year to year, animals $<25$ $\mathrm{mm}$ in shell height appear to be especially vulnerable and incur the highest mortality $(9,12)$. In areas where JOD is enzootic, JOD episodes occur late in the summer (July to September), when water temperatures exceed $20^{\circ} \mathrm{C}$ and salinities are 27 to 33 ppt $(4,9,12)$. Affected oysters first exhibit a reduction in growth rate, followed by morphological signs such as fragile and uneven shell margins, cupping of the left valve, and mantle retraction and abnormalities. In addition, a generalized host response is often manifested as the deposition of a thick ring of proteinaceous material (conchiolin) around the periphery of the mantle $(9,12)$. Deaths are observed coincident with or

* Corresponding author. Present address: Department of Biochemistry, Microbiology, and Molecular Biology, University of Maine, Orono, ME 04469. Phone: (207) 581-2822. Fax: (207) 581-2801. Email: boettche@maine.maine.edu.

$\dagger$ This is Maine Agricultural and Forestry Experiment Station Publication number 2328 . shortly after the onset of such signs, and within a period of a single week, losses may exceed $50 \%$ (4, this study).

Efforts to isolate a putative pathogen have been unsuccessful, and standard histological examinations of diseased animals have failed to reveal a conspicuous association of any single protozoan, bacterial, or viral agent $(9,17,34,35)$. Likewise, there is no evidence that JOD results from the presence of noxious phytoplankters $(28,30)$, yet the agent is believed to be biological because the disease has been successfully transmitted between animals in laboratory-maintained aquaria (30). On the basis of the accumulated evidence, and because there seems to be no other plausible origin, it is now generally believed that JOD is caused by a previously unrecognized protistan or bacterial pathogen.

Some researchers have observed coccoid bodies of uncertain origin in the mantle lesions of JOD-affected animals (9, 16, 29, 39). These Feulgen-positive basophilic bodies have been interpreted as either evidence of a parasitic life stage $(16,29,39)$ or degenerating oyster hemocytes (9). Additionally, there has been success in reducing mortalities of experimentally infected animals with erythromycin (30). This result was interpreted by the investigators to be consistent with a protistan etiology because this antibiotic may be effective against some protists. However, considering that the primary use of erythromycin is to control bacterial infections, this result is not compelling evidence that excludes bacteria as the etiological agent.

Bacteria have been observed in mantle lesions of JOD-affected animals (9), and there are striking similarities between JOD and the brown ring disease of Manila clams caused by the bacterium Vibrio tapetis $(8,18,32,33)$. To test the hypothesis that JOD may be caused by a Vibrio sp., Lee et al. (28) con- 
ducted an extensive study in which Vibrio levels in cultured juvenile oysters and water and sediment samples were monitored from May to September of 1993 at a nursery in New York that experiences seasonal deaths due to JOD. Concentrations of Vibrio spp. in both sediments and oysters were observed to significantly increase once the water temperature exceeded $20^{\circ} \mathrm{C}$, and deaths of juveniles were observed shortly thereafter (within 1 to 2 weeks). However, no single Vibrio sp. was consistently isolated from JOD animals, and attempts to reproduce JOD signs with a number of Vibrio isolates were unsuccessful. The potential involvement of bacteria other than Vibrio spp. in JOD-associated deaths was not investigated.

In this study, we used the antibacterial agents norfloxacin and sulfadimethoxine-ormetoprim (5:1) (Romet-B; Ziegler Brothers, Gardners, Pa.) in an effort to help elucidate the etiology of JOD. These antibiotics are both broad spectrum and bactericidal via inhibition of DNA unwinding and folic acid synthesis, respectively $(14,20)$. Specifically, we were interested in determining if the onset and impact of JOD could be affected by exposure to antibacterials. In addition, in an effort to discern the involvement of bacteria other than Vibrio spp., a nonselective medium was used for bacteriological analyses to maximize the recovery of total viable bacteria from healthy, JOD-affected, and recovered oysters.

\section{MATERIALS AND METHODS}

Media and antibiotics. Bacteria were isolated and maintained on a seawaterbased complex medium (SWT) (7). Strains were stored at $-80^{\circ} \mathrm{C}$ in SWT containing $12.5 \%$ glycerol. Hugh-Leifson oxidative-fermentative medium was prepared as previously described (40).

Stock solutions of norfloxacin (Sigma, St. Louis, Mo.) and sulfadimethoxineormetoprim were prepared in $1 \mathrm{~N} \mathrm{NaOH}$ (Baker, Phillipsburg, N.J.) at $20 \mathrm{mg}$ $\mathrm{ml}^{-1}$. Bath solutions contained each antibiotic at $20 \mu \mathrm{g}$ of active ingredients $\mathrm{ml}^{-1}$ and $\mathrm{NaHCO}_{3}$ at $1 \%$ (wt/vol) in filter-sterilized seawater (FSSW).

Oyster treatments and deployment. Approximately 9,000 juvenile $C$. virginica (2.5-mm shell height) were obtained from a local shellfish hatchery. Ten animals were set aside for subsequent bacteriological analysis. The remaining animals were divided into three equal groups, and each group was treated in triplicate (approximately 1,000 animals per treatment) by immersion in either FSSW or a norfloxacin or sulfadimethoxine-ormetoprim solution for a period of $3 \mathrm{~h}$. The animals were then rinsed with seawater, and each container of 1,000 animals was again divided into two equal groups. One group of each of these pairs was designated the repeat-treatment group and thereafter received weekly treatments of the corresponding antibiotic or FSSW. The other group of each pair was designated the single-treatment group and was not subsequently exposed to either antibiotic or FSSW.

Each group of approximately 500 animals was placed into open-ended mesh bags $\left(33\right.$ by $61 \mathrm{~cm}$ ) constructed of fiberglass window screen $\left(1-\mathrm{mm}^{2}\right.$ openings) for a density of approximately $5,000 \mathrm{~m}^{-2}$. Each bag was then closed via attachment to a rectangular frame $(36$ by $36 \mathrm{~cm}$ ) constructed of 0.5 -in. PVC pipe, placed into buoyant polyethylene cages ( 7.6 by 41 by $51 \mathrm{~cm}$ ), and deployed at a commercial nursery on the Damariscotta River in Maine $\left(44^{\circ} 1^{\prime} 00^{\prime \prime} \mathrm{N}, 69^{\circ} 32^{\prime} 45^{\prime \prime} \mathrm{W}\right)$. Water temperature at this site was recorded every $12 \mathrm{~h}$ by an automatic temperature logger (Ryan RTM 2000; Ryan Instruments, Redmond, Wash.), and salinity measurements were taken weekly with an optical refractometer.

Weekly sampling and monitoring. At 1-week intervals after the initial date of deployment, all 18 bags of animals were retrieved from the floating trays. Each bag of animals in the repeat-treatment group was emptied into a separate container (nine total) and reexposed via immersion to the assigned treatment for $3 \mathrm{~h}$. During this time, animals in the single-treatment group were left in their bags and kept immersed in flowing seawater. After removal from the treatment solutions, the repeat-treatment animals were rinsed in fresh seawater. The total numbers of live and dead animals in all groups were recorded, and dead animals (i.e., empty shells and those with decaying meat) were removed. Growth performance was monitored by measuring the shell heights, with digital calipers $( \pm 0.1$ $\mathrm{mm}$ ), of 30 randomly selected animals from each bag. Sampling for bacteriological analyses was conducted biweekly. At least three animals were removed from each bag, sealed in waterproof baggies, and packed in ice. Each week following the completion of sampling, all bags were redeployed in floating cages at the nursery site.

Mortality assessment and statistical analyses. Instantaneous mortality $(i)$ represents the percentage of animals on any given date that had died during the interval since the previous sampling date. Thus, each week, the number of animals redeployed at the nursery site equaled the total number of animals alive at the end of the previous week minus the number of animals that had died $(i)$ and the number of animals removed for further analyses. Cumulative mortality $(\mathrm{CM})$ is derived from the instantaneous-mortality rates and is expressed as $\mathrm{CM}=1-e^{\Sigma i}(23)$.

Mortality data were subjected to the arcsine transformation prior to analysis (44). A standard one-way analysis of variance and Dunnett's post-hoc test ( $\alpha=$ 0.05 ) were conducted on the transformed CM data by using the Statmost 3.5 statistical package (Dataxiom Software, Inc., Los Angeles, Calif.). Growth data were analyzed by using a standard analysis of variance and Dunnett's post-hoc test.

Bacteriological analyses of oysters. The 10 seed animals were homogenized whole (in two groups of five) in $0.5 \mathrm{ml}$ of sterile $70 \%$ seawater. The samples were serially diluted in sterile $70 \%$ seawater and spread onto SWT agar plates. On all other dates, unless otherwise noted, animals from any given tray were processed together. After rinsing with FSSW $(3 \times 40 \mathrm{ml}$ in a sterile petri plate), the adductor muscle of each animal was severed by using a flame-sterilized scalpel and forceps. Tissues were removed and combined in $0.4 \mathrm{ml}$ of sterile $70 \%$ seawater and homogenized with a sterile pellet pestle. The samples were then diluted and plated as described above. All plates were incubated for 7 days at $23^{\circ} \mathrm{C}$ before enumeration of CFUs to estimate total recoverable bacteria. The culture plates were also inspected visually for the presence of numerically dominant colony morphologies, and representatives of abundant types were transferred to fresh medium for further characterization.

Phenotypic analyses of bacteria. Determination of Gram reaction, motility (in a wet mount), catalase activity, oxidase activity, and reaction in oxidative-fermentative medium were performed in accordance with standard methods (40). The capacity for anaerobic growth was tested by using an anaerobic-bag system (Marion Scientific, Kansas City, Mo.). Selected isolates were also tested for growth on Marine Agar 2216 (Difco) and thiocitrate sucrose bile salts medium (BBL, Cockeysville, Md.)

Twenty-five selected oyster isolates and five control strains (two Escherichia coli and three Aeromonas salmonicida) were tested for susceptibility to norfloxacin and sulfadimethoxine-ormetoprim in a disk diffusion assay. The oyster isolates were unable to grow on the standard antibiotic testing medium (MuellerHinton agar), so all testing was performed on SWT agar. Bacteria from agar plates were inoculated into $5 \mathrm{ml}$ of SWT broth and grown to an optical density at $600 \mathrm{~nm}$ of 0.16 (equivalent to a $0.5 \mathrm{McF}$ arland turbidity standard) or adjusted to this density with diluent if necessary. A sterile cotton swab was moistened with the standardized bacterial suspension and used to inoculate the surface of a 150-mm-diameter SWT agar plate. A disk impregnated with either norfloxacin $(10 \mu \mathrm{g})$ or sulfadimethoxine $(23.8 \mu \mathrm{g})$-ormetoprim $(1.2 \mu \mathrm{g})$ was applied to the center of either half of the inoculated plate. All plates were incubated at $23^{\circ} \mathrm{C}$, and the resulting zones of inhibition were measured with digital calipers to the nearest millimeter.

DNA purification, amplification of 16S rRNA genes (rDNAs), and sequence analysis. Genomic DNA was prepared from bacterial cultures as described by Meade et al. (31) and diluted to $10 \mu \mathrm{g} \mathrm{ml}^{-1}$ in $10 \mathrm{mM}$ Tris-HCl-1 mM EDTA $(\mathrm{pH} 8.0)$. The primers used for amplification of 16S rDNAs were previously described (26) and correspond to E. coli positions 8 to 27 (primer 27F) and 1492 to 1510 (primer 1492R). Each $50-\mu \mathrm{l} \mathrm{PCR}$ mixture contained $50 \mathrm{ng}$ of genomic DNA, $2 \mathrm{mM} \mathrm{MgCl}_{2}$, amplification primers (100 nM each), and $200 \mu \mathrm{M}$ each deoxynucleoside triphosphate in $1 \times$ thermophilic DNA polymerase buffer (Promega, Madison, Wis.). After an initial 4-min denaturing step $\left(94^{\circ} \mathrm{C}\right)$, one wax Taq bead (Promega Hot Start; $1.25 \mathrm{U} /$ bead) was added to each reaction tube and the tubes were held at $94^{\circ} \mathrm{C}$ for an additional $2 \mathrm{~min}$. The thermocycler (Techne Ltd., Duxford Cambridge, United Kingdom) was then set to run 35 cycles under the following conditions: $40 \mathrm{~s}$ of denaturing $\left(94^{\circ} \mathrm{C}\right), 30 \mathrm{~s}$ of annealing $\left(62^{\circ} \mathrm{C}\right)$, and $60 \mathrm{~s}$ of elongation $\left(72^{\circ} \mathrm{C}\right)$, followed by an additional $7 \mathrm{~min}$ of elongation at the end of the program. The PCR products were purified by using a Centricon-100 microconcentrator (Amicon Inc., Beverly, Mass.), and the purity and concentration of the DNA were analyzed by electrophoresis on a $1 \%$ agarose gel (36). The purified products were sequenced at the University of Maine's DNA sequencing facility by using the ABI Prism Dye Terminator Cycle Sequencing Ready Reaction Kit with Amplitaq DNA polymerase FS (Applied Biosystems Inc., Foster City, Calif.). The primers used for sequencing included $27 \mathrm{~F}$ and $1492 \mathrm{R}$, as well as 530F, 519R, 907R, and 926F $(26,27)$.

An unambiguous consensus sequence of 1,390 bp was produced by analysis with Sequence Navigator software (Applied Biosystems, Inc.) and subjected to BLAST analysis (2). The three sequences identified by the BLAST program as producing significant alignments were downloaded and manually aligned with the $C$. virginica small pink (CVSP) colony type sequence across 1,294 nucleotides. Gaps were not included in the calculation of percent nucleotide identity between aligned sequences.

Nucleotide sequence accession numbers. The nucleotide sequences of the strain CV919-312 and CV1010-362 rDNAs have been submitted to GenBank and assigned accession no. AF114484 and AF114485, respectively.

\section{RESULTS}

Environmental conditions. Water temperature at the nursery site had reached $21^{\circ} \mathrm{C}$ approximately 3 weeks prior to the deployment date (Fig. 1). In the weeks thereafter, mean tem- 


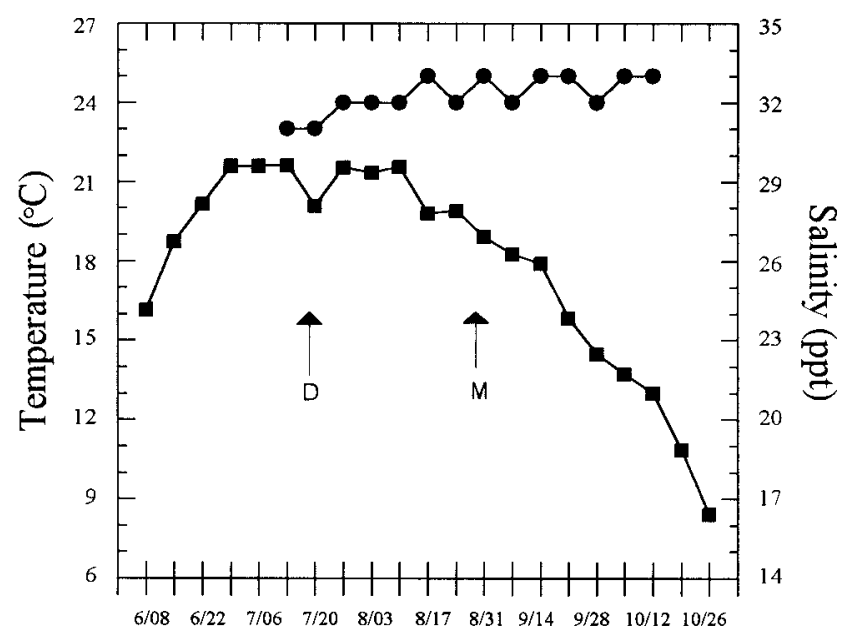

Date

FIG. 1. Mean weekly water temperature $(\boldsymbol{\square})$ and salinity $(\mathbf{0})$ at the Damariscotta River nursery site from June to November 1997. The deployment date (D) and onset of deaths (M) are indicated.

peratures stayed between 20 and $22^{\circ} \mathrm{C}$ before the first deaths due to JOD occurred in late August. The water temperature was $19^{\circ} \mathrm{C}$ when deaths began occurring and continued to decrease throughout the period during which deaths due to JOD occurred. Salinities were fairly constant (between 30 and 33 ppt) from July to November (Fig. 1).

Growth and JOD onset. Juvenile $C$. virginica in all groups exhibited rapid growth during the first 4 weeks following deployment at the nursery site (Fig. 2). However, between 13 and 20 August, little growth was noticed in the three single-treatment groups and the FSSW repeat-treatment group (Fig. 2). In addition, animals in these four groups had developed other characteristic signs of JOD, including fragility of the shell margins, exaggerated cupping of the left valve, and mantle retraction. Juveniles receiving weekly treatments of sulfadimethox-

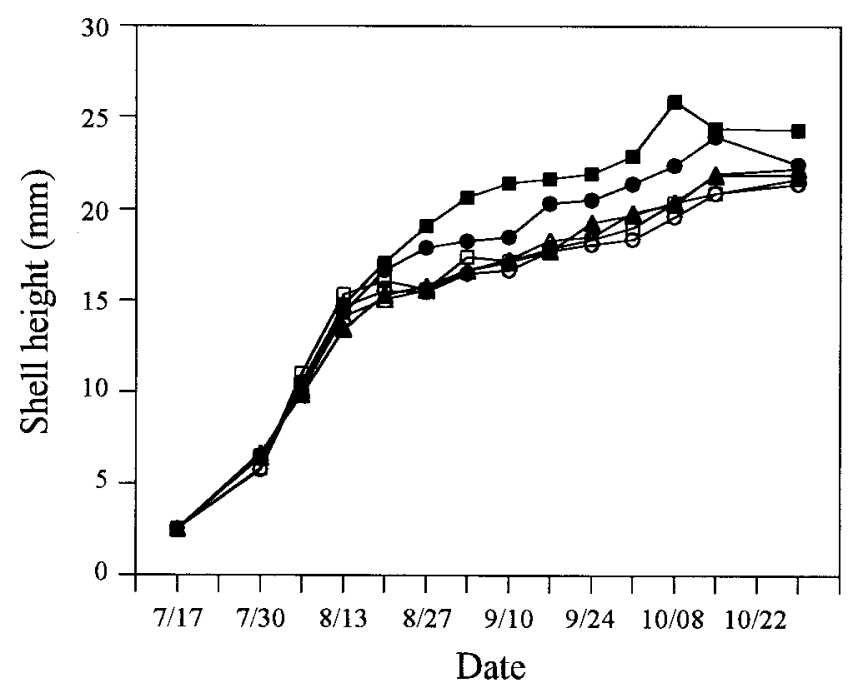

FIG. 2. Growth of experimental groups of $C$. virginica. The mean shell height of 30 randomly selected animals from each triplicate bag was determined and then used to derive the mean shell height of each experimental group. Symbols: $\triangle$, single FSSW treatment; $\bigcirc$, single sulfadimethoxine-ormetoprim treatment; $\square$, single norfloxacin treatment; $\boldsymbol{\Delta}$, repeat FSSW treatment; $\boldsymbol{\bullet}$, repeat sulfadimethoxine-ormetoprim treatment; $\mathbf{\square}$, repeat norfloxacin treatment.

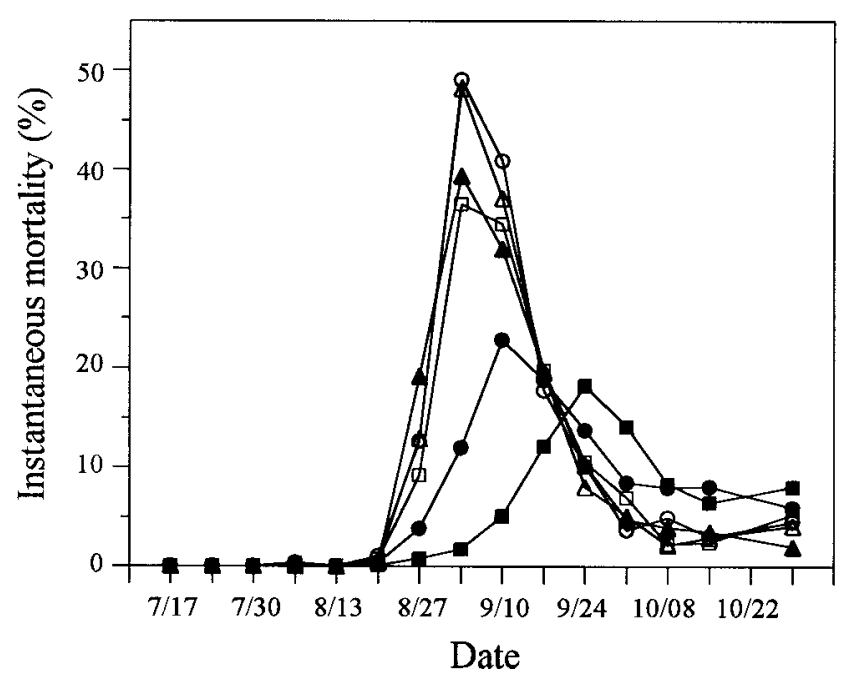

FIG. 3. Weekly mortality rates of experimental groups of $C$. virginica. Rates were calculated as described in Materials and Methods, and the symbols are as defined in the legend to Fig. 2. The data represent the mean of three replicate trays in each group.

ine-ormetoprim and norfloxacin had also begun to show overt signs of JOD at this time, but fewer individuals appeared to be affected, and the signs were less pronounced. Reductions in the growth rates of animals in the sulfadimethoxine-ormetoprim and norfloxacin repeat-treatment groups were not observed for another 1 and 2 weeks, respectively.

Animals exposed weekly to the antibacterials exhibited overall better growth. On each sampling date after 27 August, the mean shell height of animals in the norfloxacin repeat-treatment group was significantly greater $(P \leq 0.05)$ than that of animals in the single-treatment groups and the FSSW repeattreatment group. Animals in the sulfadimethoxine-ormetoprim repeat-treatment group achieved greater shell heights than animals that had received only a single treatment with either norfloxacin or sulfadimethoxine-ormetoprim. These differences were statistically significant on four of the six sampling dates after 10 September.

Effect of antibiotics on mortality due to JOD. Greater than $99 \%$ of all deaths were associated with overt signs of JOD. Deaths were first observed on 27 August, and the highest instantaneous mortality rates for animals in the single-treatment and FSSW repeat-treatment groups were observed on 3 September (Fig. 3). Repeated exposure to sulfadimethoxineormetoprim resulted in a 1-week delay in maximum instantaneous mortality rates, while the norfloxacin repeat-treatment groups did not exhibit peak mortalities until 24 September, 3 weeks after the highest mortalities occurred in the FSSW repeat-treatment group and all of the single-treatment groups (Fig. 3). Instantaneous mortality rates in the sulfadimethoxineormetoprim and norfloxacin repeat-treatment groups did not exceed $25 \%$, compared to peak mortality rates of between 35 and $50 \%$ in animals in the single-treatment groups and FSSW repeat-treatment animals (Fig. 3 ).

CMs in the single-treatment groups were 77,84 , and $82 \%$ for the norfloxacin, sulfadimethoxine-ormetoprim, and FSSW treatments, respectively (Fig. 4). Similarly, $81 \%$ of the animals in the FSSW repeat-treatment group died from JOD. Weekly treatments with either norfloxacin or sulfadimethoxineormetoprim resulted in statistically significant reductions in CM of 55 and $67 \%$, respectively (Fig. $4 ; P=0.00008$ ). 


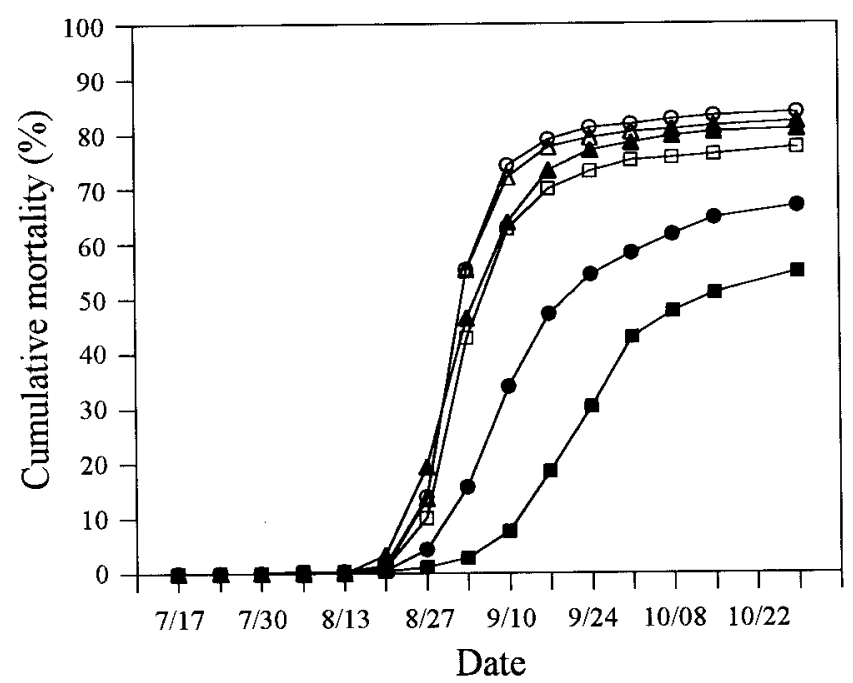

FIG. 4. CM of experimental groups of $C$. virginica. Calculations are described in Materials and Methods, and symbols are defined in the legend to Fig. 2. The data represent the mean of three replicate trays in each group.

Bacterial counts and presence of a dominant colony type. Juvenile oysters obtained from the hatchery contained approximately $9.0 \times 10^{4}$ recoverable CFUs per animal (meat and shells combined). All subsequent bacteriological analyses were conducted on aseptically dissected tissues. Throughout the course of the study, the total number of bacteria recovered

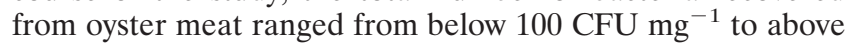
$3 \times 10^{3} \mathrm{CFU} \mathrm{mg}^{-1}$. Still, the lowest counts were obtained in samples prior to the onset of JOD, while samples that included animals showing overt signs of JOD yielded counts that were elevated approximately 10 -fold. For example, the mean numbers of CFUs recovered from oysters before (13 August) and after (27 August) the onset of mortality due to JOD were $3.0 \times$ $10^{2}$ and $1.6 \times 10^{3} \mathrm{mg}^{-1}$, respectively. In addition, five apparently healthy animals and five animals with JOD signs were removed on 10 September and processed individually for bacteriological analyses. Samples from animals without overt signs of JOD yielded $2.0 \times 10^{2} \mathrm{CFU} \mathrm{mg}^{-1}$, while $1.7 \times 10^{3} \mathrm{CFU}$ $\mathrm{mg}^{-1}$ were recovered from affected animals.

Based on visual inspection of colony types, there was a high diversity of bacteria isolated from the hatchery seed oysters and oyster meat prior to 27 August. That is, on plates with between 20 and 200 CFUs, it was unusual for any colony morphology to represent more than $10 \%$ of the total isolates. However, beginning on 27 August and continuing throughout the period during which deaths due to JOD occurred, the presence of a numerically dominant colony type was observed. These colonies took 4 to 5 days to achieve a diameter of $1 \mathrm{~mm}$ on SWT agar and comprised between 30 and $95 \%$ of the total recoverable CFUs (Fig. 5). They were uniformly round, nonmucoid, and nonpigmented until after approximately 7 days, when the colonies exhibited a distinct light pink coloration (the CVSP colony type). Frozen stocks of 120 isolates recovered over a 7-week period were stored for further characterization.

On the last sampling date (29 October), many animals exhibited renewed shell growth (a sign of improved health). Bacteriological analyses of these animals $(n=6)$ revealed an absence or very low prevalence of CVSP bacteria $(<1 \%$ of the total CFUs). In contrast, CVSP bacteria were still isolated at this time in significant numbers (between 18 and $60 \%$ of the total CFUs) from animals that did not exhibit such signs of recovery from JOD.

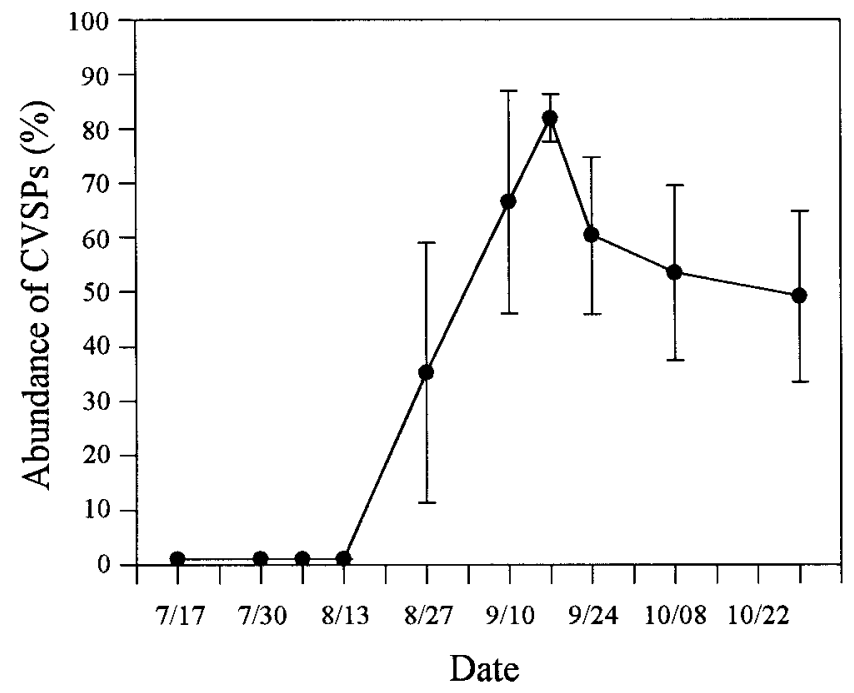

FIG. 5. Percentages of total CFUs recovered from weekly samples that exhibited the distinct colony morphology of CVSP bacteria as described in the text. The data represent the mean of six experimental groups, and the error bars represent 1 standard deviation.

Characterization of the dominant CFU. All 120 CVSP isolates exhibited the following characteristics. They were gramnegative rods (approximately 0.25 by $1.0 \mu \mathrm{m}$ ), exhibited flagellar motility, were oxidase positive, were weakly catalase positive, and produced no reaction in oxidative-fermentative medium. Of 10 isolates tested, none were found to be capable of anaerobic growth. The 25 isolates tested for susceptibility to norfloxacin and sulfadimethoxine-ormetoprim exhibited similar sensitivities to these antibiotics (Table 1). The average zone of inhibition resulting on CVSP bacterium-inoculated plates was at least twice the size recorded for each of the resistant control organisms tested.

Genomic DNA was prepared from two CVSP bacteria

TABLE 1 . Susceptibility of norfloxacin-sensitive and norfloxacinresistant $E$. coli, sulfadimethoxine-ormetoprim-sensitive and sulfadimethoxine-ormetoprim-resistant $A$. salmonicida, and CVSP isolates to norfloxacin and sulfadimethoxine-ormetoprim

\begin{tabular}{|c|c|c|c|c|}
\hline \multirow[b]{2}{*}{ Organism(s) } & \multirow{2}{*}{$\begin{array}{c}\text { Source or } \\
\text { isolation date }\end{array}$} & \multirow{2}{*}{$\begin{array}{l}\text { No. of } \\
\text { strains }\end{array}$} & \multicolumn{2}{|c|}{$\begin{array}{l}\text { Mean inhibition zone } \\
\text { diam }(\mathrm{mm})^{a} \pm \mathrm{SD}\end{array}$} \\
\hline & & & $\begin{array}{l}\text { Nor- } \\
\text { floxacin }\end{array}$ & $\begin{array}{c}\text { Sulfa- } \\
\text { dimethoxine- } \\
\text { ormetoprim }\end{array}$ \\
\hline E. coli $\mathrm{KD} 65$ & Drlica and Zhao & 1 & 37 & 30 \\
\hline E. coli $\mathrm{KD}^{2} 6^{c}$ & Drlica and Zhao & 1 & 22 & 22 \\
\hline A. salmonicida 80204 & G. Olivier & 1 & 39 & 21 \\
\hline A. salmonicida $96276^{d}$ & G. Olivier & 1 & 41 & 6 \\
\hline A. salmonicida $96362^{d}$ & G. Olivier & 1 & 39 & 6 \\
\hline CVSP isolates & 09/17/97 & 5 & $48 \pm 1.3$ & $19 \pm 0.9$ \\
\hline CVSP isolates & $09 / 24 / 97$ & 5 & $49 \pm 1.6$ & $19 \pm 1.7$ \\
\hline CVSP isolates & $10 / 01 / 97$ & 5 & $51 \pm 1.8$ & $21 \pm 2.0$ \\
\hline CVSP isolates & $10 / 08 / 97$ & 5 & $51 \pm 0.9$ & $20 \pm 1.9$ \\
\hline CVSP isolates & $10 / 29 / 97$ & 5 & $51 \pm 1.2$ & $21 \pm 2.2$ \\
\hline
\end{tabular}

${ }^{a}$ Zones were measured after 48-h incubation of $E$. coli and $A$. salmonicida and after 72-h incubation of CVSP isolates. Five CVSP isolates collected on each of five isolation dates were tested. Each disk (impregnated with either norfloxacin $[10 \mu \mathrm{g}]$ or sulfadimethoxine [23.8 $\mu \mathrm{g}]$-ormetoprim $[1.2 \mu \mathrm{g}]$ ) was $6 \mathrm{~mm}$ in diameter, and all zones were measured to the nearest millimeter.

${ }^{b}$ This study was the source of all of the CVSP isolates tested.

${ }^{c}$ Norfloxacin-resistant strain.

${ }^{d}$ Sulfadimethoxine-ormetoprim-resistant strain 
(strains CV919-312 and CV1010-362) that had been isolated 3 weeks apart. Using PCR, we amplified 16S rDNAs from these strains; we then purified the products and submitted them for sequencing. These rDNAs yielded identical unambiguous sequences of $1,390 \mathrm{bp}$. The $16 \mathrm{~S}$ rDNAs of $\alpha$-proteobacterium MBIC3951, Roseovarius tolerans (24), and marine bacterium isolate SRF3 were identified by the BLAST program as producing the most significant alignments with the CVSP sequence. The corresponding accession numbers of these sequences are AB018689, Y11551, and AJ002565. The sequence identity percentages of the sequences aligned (excluding gaps) with the CVSP sequence were calculated to be 96.0, 94.8, and $94.4 \%$, respectively.

\section{DISCUSSION}

The transmissibility of JOD among oysters held in artificial seawater (30) suggests that JOD is caused by a biological agent. Specifically, a previously unknown bacterial or protistan pathogen is believed to be involved, although certain environmental factors and/or abiotic agents may also contribute to the development of JOD in areas where JOD is enzootic. Antibacterial agents were used in the current study for the sole purpose of gaining insight into the nature of the JOD agent. Norfloxacin and sulfadimethoxine-ormetoprim were selected because they possess the following desired properties: (i) a broad spectrum of activity against bacteria (and each agent affects essential but unrelated bacterial enzymes); (ii) bactericidal rather than bacteriostatic activity, making them useful for short-term immersions; (iii) selective toxicity for bacteria; and (iv) activity and stability in seawater (1, 10, 14, 20, 42).

The effects of a single immersion and a weekly immersion regimen were tested because we believed that there could be three principle processes by which bacteria might be involved in deaths due to JOD. First, generalized bacterial colonization of seed oysters in the warm, nutrient-rich environment of a shellfish hatchery might predispose animals to infection by the primary JOD agent (bacterial or protistan). Alternatively, seed oysters could be colonized by a specific bacterium during production in a hatchery that later (given the appropriate environmental conditions) may contribute to mortality due to JOD. Lastly, the oysters may become colonized by a primary bacterial agent and/or secondary opportunists after deployment at sites where JOD is enzootic.

To date, the occurrence of JOD has not been correlated with the source of seed oysters $(5,9,17)$. Together with our finding that the timing and patterns of JOD-induced mortality were similar in animals that either received a single-treatment bath or were exposed to just FSSW (either on the day of deployment or weekly), we think it is unlikely that hatchery-acquired bacteria contribute either directly or indirectly to JOD. Instead, the delay and reduction in animal mortality observed when a repeat antibiotic exposure schedule was used are consistent with the presence of an infective bacterium at the site where JOD is enzootic.

Animals receiving weekly treatment with either norfloxacin or sulfadimethoxine-ormetoprim exhibited significantly enhanced growth. Although previous experiments have shown that larger animals are less susceptible to death due to JOD, in this study, all animals had achieved similar sizes when the first signs of JOD appeared. Thus, the effect of the antibacterial agents on mortality does not appear to be a side effect of this eventual growth advantage. In fact, the antibiotic treatments more likely resulted in increased growth by delaying the onset of JOD and the usual accompanying adverse effects on growth rates. Another consideration is the possible effect of declining temperatures on the reduction of the mortality rate of animals receiving repeat therapy. Specifically, both field and laboratory transmission experiments have shown that temperature is a factor in the development of $\operatorname{JOD}(9,30)$. However, although cooler water temperatures may result in a delay in the onset of external signs of JOD, CM is not ultimately reduced compared to that of cohorts reared at a warmer site (13). Thus, the results of our study indicate that the delay and significant reduction of deaths due to JOD experienced by animals exposed to weekly 3-h immersions in either norfloxacin or sulfadimethoxineormetoprim were a direct result of the bactericidal activities of these agents.

We discovered that a numerically dominant bacterium (designated CVSP) was present in JOD-affected oysters. In contrast, there were no distinct colony morphology types consistently recovered from healthy oysters (before the onset of JOD) or from animals showing renewed shell growth. The demonstrated sensitivity of the CVSP isolates to norfloxacin and sulfadimethoxine-ormetoprim is consistent with a proposed role for these bacteria in mortality due to JOD. The $16 \mathrm{~S}$ rDNA sequences of two representative CVSP isolates were found to be identical and aligned most closely with the $16 \mathrm{~S}$ rDNAs of marine members of the $\alpha$-proteobacteria. Interestingly, several species of marine $\alpha$-proteobacteria have just recently been identified as symbionts of a variety of marine plant and animal species $(3,6,11,25,37)$ and there is growing interest in their role as members of coastal (21), Antarctic ice (22), and hydrothermal-vent (43) communities.

There are several reasons why these $\alpha$-proteobacteria may have not been reported in prior investigations of the etiology of JOD. The best explanation may be that no one suspected the primary involvement of bacteria other than Vibrio spp. in JOD. Members of this genus are the most common pathogens of cultured bivalves $(15,38)$, and there are strong similarities between JOD and a similar Vibrio-caused disease of Manila clams $(18,33)$. Consequently, investigators have specifically tried to isolate Vibrio spp. from JOD-affected animals by using enrichment techniques and selective media $(19,28,30)$ that are unsuitable for the growth of CVSP bacteria. Even when nonselective media are used, the CVSP type of bacteria may be missed because they grow slowly at $23^{\circ} \mathrm{C}$ (the temperature normally used for incubation during routine recovery of bacteria from shellfish). Many marine Vibrio spp. form visible colonies within a day at $23^{\circ} \mathrm{C}$, yet it takes at least 4 days at this temperature for a CVSP bacterium to achieve a colony diameter of $1 \mathrm{~mm}$ on either SWT or Marine Agar 2216. Other biases may be a result of how animals were treated prior to dissection. In one series of experiments, a $10 \%$ bleach solution was used to sterilize the surfaces of JOD-affected animals before dissection and processing for bacteriological analyses (30). This approach is problematic because evidence suggests that the JOD agent is primarily associated with external mantle and periostracum tissues (9). Young oysters (especially those with uneven valves that result from JOD) are unable to form a watertight seal, so it is likely that such treatment resulted in an inaccurate assessment of resident bacteria. Indeed, those investigators reported that they were unable to recover any bacteria from bleach-treated oysters by direct plating.

The results of this study provide evidence that a previously unidentified species of $\alpha$-proteobacteria is involved in JOD mortality. To our knowledge, this study also documents the first successful cultivation of marine $\alpha$-proteobacteria from a defined animal host. CVSP bacteria may be the etiological agent of JOD or efficient colonizers of affected animals. We did not observe the presence of CVSP bacteria in animals before deaths began occurring, which might indicate that these 
bacteria are opportunistic and JOD is caused by another agent(s). However, this conclusion does not seem consistent with the generalized tissue emaciation and necrosis observed in affected animals, which would be expected to support a wide variety of secondary colonizers. Alternatively, low levels of CVSP bacteria may have been present in animals before deaths began occurring but were not detected by direct plating. We are currently developing more-sensitive detection techniques for these bacteria and are conducting experiments to test for the ability of a CVSP isolate to induce JOD signs and death in juvenile $C$. virginica.

\section{ACKNOWLEDGMENTS}

This study was funded by the Maine Aquaculture Innovation Center and a NOAA Sea Grant (R/FMD-235 and R/FMD-245).

We are grateful to Mook Sea Farms and Pemaquid Oyster Company for their generous assistance with this study. We also thank P. B. Singer for her excellent sequencing services and R. B. Carnegie for providing helpful comments on the manuscript. The E. coli strains were a gift from X. Zhao and K. Drlica, and G. Olivier graciously provided the A. salmonicida strains.

\section{REFERENCES}

1. Albertini, S., A.-A. Chetalat, B. Miller, W. Muster, E. Pujadas, R. Strobel, and E. Gocke. 1995. Genotoxicity of 17 gyrase- and four mammalian topoisomerase II-poisons in prokaryotic and eukaryotic test systems. Mutagenesis 10:343-351

2. Altschul, S. F., T. L. Madden, A. A. Schaffer, J. Zhang, Z. Zhang, W. Miller, and D. J. Lipman. 1997. Gapped BLAST and PSI-BLAST: a new generation of protein database search programs. Nucleic Acids Res. 25:3389-3402.

3. Ashen, J. B., and L. J. Goff. 1996. Molecular identification of a bacterium associated with gall formation in the marine red alga Prionitis lanceolata. J. Phycol. 32:286-297.

4. Barber, B. J., R. B. Carnegie, C. V. Davis, and W. Mook. 1996. Effect of timing of seed deployment on growth and mortality of oysters, Crassostrea virginica, affected by juvenile oyster disease (JOD). J. World Aquacult. Soc. 27:443-448

5. Barber, B. J., C. V. Davis, and M. A. Crosby. 1998. Cultured oysters, Crassostrea virginica, genetically selected for fast growth in the Damariscotta River, Maine, are resistant to mortality caused by juvenile oyster disease (JOD). J. Shellfish Res. 17:1171-1175.

6. Barbieri, E., J. Gulledge, D. Moser, and C.-C. Chien. 1996. New evidence for bacterial diversity in the accessory nidamental gland of the squid (Loligo pealei). Biol. Bull. 191:316-317.

7. Boettcher, K. J., and E. G. Ruby. 1990. Depressed light emission by symbiotic Vibrio fischeri of the sepiolid squid Euprymna scolopes. J. Bacteriol. 172: 3701-3706.

8. Borrego, J. J., D. Castro, A. Luque, C. Paillard, P. Maes, M. T. Garcia, and A. Ventosa. 1996. Vibrio tapetis sp. nov., the causative agent of the brown ring disease affecting cultured clams. Int. J. Syst. Bacteriol. 46:480-484.

9. Bricelj, V. M., S. E. Ford, F. J. Borerro, F. O. Perkins, G. Rivara, R. E. Hillman, R. A. Elston, and J. Chang. 1992. Unexplained mortalities of hatchery-reared, juvenile oysters, Crassostrea virginica (Gmelin). J. Shellfish Res. 11:331-347.

10. Bullock, G. L., G. Maestrone, C. Storliper, and B. Schill. 1983. Potentiated sulfonamide therapy of enteric redmouth disease. Can. J. Fish. Aquat. Sci. 40:101-102.

11. Burnett, W. J., and J. D. McKenzie. 1997. Subcuticlar bacteria from the brittle star Ophiactis balli (Echinodermata: Ophiuroidea) represent a new lineage of extracellular marine symbionts in the $\alpha$ subdivision of the class Proteobacteria. Appl. Environ. Microbiol. 63:1721-1724.

12. Davis, C. V., and B. J. Barber. 1994. Size-dependent mortality in hatcheryreared populations of oysters, Crassostrea virginica, Gmelin 1791, affected by juvenile oyster disease. J. Shellfish Res. 13:137-142.

13. Davis, C. V., and B. J. Barber. Growth and survival of genetically selected Eastern oysters, Crassostrea virginica (Gmelin 1791), affected by juvenile oyster disease. Aquaculture, in press.

14. Drlica, K., and X. Zhao. 1997. DNA gyrase, topoisomerase IV, and the 4-quinolones. Microbiol. Mol. Rev. 61:377-392.

15. Elston, R. A. 1984. Prevention and management of infectious diseases in intensive mollusc husbandry. J. World Mariculture Soc. 15:284-300.

16. Farley, C. A., and E. J. Lewis. 1995. Juvenile oyster disease studies 1994: epizootiology, geographic occurrence. J. Shellfish Res. 14:241-242.

17. Ford, S. E. 1994. Unexplained mortalities of hatchery-reared oysters, Cras- sostrea virginica, in the Northeast: a followup study. Final report to the Northeastern Regional Aquaculture Center. University of Massachusetts Dartmouth, North Dartmouth.

18. Ford, S. E., and C. Paillard. 1994. A comparison of juvenile oyster disease in the USA and brown ring disease of Manila clams in Europe. J. Shellfish Res. 13:314.

19. Ford, S. E., G. Taylor, M. Lee, M. Bricelj, and J. Grochowski. 1994. The role of bacteria and microalgae in unexplained juvenile oyster mortalities. Final report to the Northeastern Regional Aquaculture Center. University of Massachusetts Dartmouth, North Dartmouth

20. Fraser, C. M., J. A. Bergeron, A. Mays, and S. E. Aiello (ed.). 1991. The Merck veterinary manual. 7th ed. Merck \& Co., Inc., Rahway, N.J.

21. Gonzalez, J. M., and M. A. Moran. 1997. Numerical dominance of a group of marine bacteria in the $\alpha$-subclass of the class Proteobacteria in coastal seawater. Appl. Environ. Microbiol. 63:4237-4242.

22. Gosink, J. J., and J. T. Staley. 1995. Biodiversity of gas vacuolate bacteria from Antarctic sea ice and water. Appl. Environ. Microbiol. 61:3486-3489.

23. Krebs, C. H. 1972. Ecology-the experimental analysis of distribution and abundance. Harper \& Row, Inc., New York, N.Y.

24. Labrenz, M., M. D. Collins, P. A. Lawson, B. J. Tindall, P. Schumann, and P. Hirsch. 1999. Roseovarius tolerans gen. nov., sp. nov., a budding bacterium with variable bacteriochlorophyll $a$ production from hypersaline Ekho Lake. Int. J. Syst. Bacteriol. 49:137-147.

25. Lafay, B., R. Ruimy, C. Rausch de Traubenberg, V. Breittmayer, M. J. Gauthier, and R. Christen. 1995. Roseobacter algicola sp. nov., a new marine bacterium isolated from the phycosphere of the toxin-producing dinoflagellate Prorocentrum lima. Int. J. Syst. Bacteriol. 45:290-296.

26. Lane, D. J. 1991. 16S/23S rRNA sequencing, p. 115-175. In E. Stackebrandt and M. Goodfellow (ed.), Nucleic acid techniques in bacterial systematics. John Wiley \& Sons, Inc., New York, N.Y.

27. Lane, D. J., B. Pace, G. J. Olsen, D. A. Stahl, M. L. Sogin, and N. R. Pace. 1985. Rapid determination of $16 \mathrm{~S}$ ribosomal RNA sequences for phylogenetic analyses. Proc. Natl. Acad. Sci. USA 82:6955-6959.

28. Lee, M., G. T. Taylor, V. M. Bricelj, S. E. Ford, and S. Zahn. 1996. Evaluation of Vibrio spp. and microplankton blooms as causative agents of juvenile oyster disease in Crassostrea virginica (Gmelin, 1791). J. Shellfish Res. 15: 319-330.

29. Lewis, E. J., and C. A. Farley. 1995. Transmission and filtration studies of juvenile oyster disease (JOD). J. Shellfish Res. 14:243-244.

30. Lewis, E. J., C. A. Farley, E. B. Small, and A. M. Baya. 1996. A synopsis of juvenile oyster disease (JOD) experimental studies in Crassostrea virginica. Aquat. Living Resour. 9:169-178.

31. Meade, H. M., S. R. Long, G. B. Ruvkin, S. E. Brown, and F. M. Ausubel. 1982. Physical and genetic characterization of symbiotic and auxotrophic mutants of Rhizobium meliloti induced by transposon Tn5 mutagenesis. J. Bacteriol. 149:114-122.

32. Paillard, C., and P. Maes. 1990. Etiologie de la maladie de l'anneau brun chez Tapes phillipinarum: pathogenicite d'un Vibrio sp. C. R. Acad. Sci. (Paris) 310:15-20.

33. Paillard, C., P. Maes, and R. Oubella. 1994. Brown ring disease in clams. Annu. Rev. Fish Dis. 4:219-240.

34. Rask, K. 1992. Unexplained oyster mortalities in New England: 1989-1990. Environ. Manag. 16:523.

35. Relyea, D. 1992. Unexplained mortalities in juvenile hatchery-reared oysters. Environ. Manag. 16:523.

36. Sambrook, J., E. F. Fritsch, and T. Maniatis. 1989. Molecular cloning: a laboratory manual, 2nd ed. Cold Spring Harbor Laboratory Press, Plainview, N.Y.

37. Shiba, T. 1991. Roseobacter litoralis gen. nov., sp. nov., and Roseobacter denitrificans sp. nov., aerobic pink-pigmented bacteria which contain bacteriochlorophyll $a$. Syst. Appl. Microbiol. 14:140-145.

38. Sinderman, C. 1990. Principal diseases of marine fish and shellfish. Academic Press, Inc., New York, N.Y.

39. Small, E. B. 1995. Ciliated protists associated with juvenile oyster disease. J. Shellfish Res. 14:247-248.

40. Smibert, R. M., and N. Krieg. 1994. Phenotypic characterization, p. 607-651. In P. Gerhardt, R. G. E. Murray, W. A. Wood, and N. Krieg (ed.), Methods for general and molecular bacteriology. American Society for Microbiology, Washington, D.C

41. Spatz, M. J., J. L. Anderson, and S. Jancart. 1996. Northeast region aquaculture industry situation and outlook report. Northeastern Regional Aquaculture Center, North Dartmouth, Mass.

42. Stoffregen, D. A., P. R. Bowser, and J. G. Babish. 1996. Antibacterial chemotherapeutants for finfish aquaculture: a synopsis of laboratory and field efficacy and safety studies. J. Aquat. Anim. Health 8:181-207.

43. Yurkov, V., and J. T. Beatty. 1998. Isolation of aerobic anoxygenic photosynthetic bacteria from black smoker plume waters of the Juan de Fuca Ridge in the Pacific Ocean. Appl. Environ. Microbiol. 64:337-341.

44. Zar, J. H. 1984. Biostatistical analysis, 2nd ed. Prentice-Hall Inc., Englewood Cliffs, N.J. 